\title{
WIRELESS PH MONITORING AND CONVENTIONAL ESOPHAGEAL PH MONITORING: COMPARATIVE STUDY OF DISCOMFORT, LIMITATIONS IN DAILY ACTIVITIES AND COMPLICATIONS
}

\author{
pHmetria sem cateter e phmetria esofágica convencional: estudo comparativo do desconforto, limitações das \\ atividades diárias e complicações
}

\author{
Rimon Sobhi AZZAM ${ }^{1 \oplus}$, Gabriela Barge AZZAM $^{2 \oplus}$, Ary NASI ${ }^{1 \oplus}$
}

\begin{abstract}
Background: The catheter of the esophageal pH monitoring is associated with nasal and throat discomfort, and different behave in patients. The capsule of the wireless $\mathrm{pH}$ monitoring may cause chest pain and complications. Aim: To compare the wireless and conventional $\mathrm{pH}$ monitoring concerning the degree of discomfort and limitations in daily activities, complications, ability to diagnose pathological reflux, and costs. Methods: Twenty-five patients with symptoms of gastroesophageal reflux were prospectively submitted, in a simultaneous initial period, to 24-hour catheter esophageal pH monitoring and 48-hour wireless system. After removing each system, patients underwent a specific clinical questionnaire. Results: Fifteen patients (60\%) pointed a higher discomfort in the introduction of the capsule $(p=0.327)$. Discomfort and limitations in daily activities were lower on $2^{\text {nd }}$ day $(p<0.05)$; however, continued to be expressive $(32 \%$ to $44 \%)$. Chest pain occurred in 13 (52\%) patients. The diagnostic gain of pathological reflux was $12 \%$ with the wireless system ( $p=0.355)$. Conclusions: 1$)$ There is no significant difference between the discomfort mentioned in the introduction of the capsule and the catheter; 2) during reflux monitoring, the wireless system provides significant less discomfort and limitations in daily activities; 3 ) there is no significant difference between the two methods in the ability to diagnose pathological reflux; 4) wireless $\mathrm{pH}$ monitoring has higher cost.

HEADINGS: Gastroesophageal reflux. Esophageal pH monitoring. Wireless technology.
\end{abstract}

RESUMO - Racional: O cateter da pHmetria esofágica associa-se ao desconforto nasal e na garganta, e comportamento diferente nos pacientes. A cápsula da pHmetria sem cateter pode causar dor torácica e complicações. Objetivo: Comparar as pHmetrias sem cateter e a convencional, em relação ao desconforto e limitações das atividades diárias, complicações, capacidade de diagnosticar refluxo patológico, e custos. Métodos: Vinte e cinco pacientes com sintomas de refluxo gastroesofágico foram prospectivamente submetidos, em um período inicial simultâneo, à pHmetria esofágica com cateter durante $24 \mathrm{~h}$ e à pHmetria sem cateter durante $48 \mathrm{~h}$. Após a retirada de cada método, pacientes responderam o questionário clínico específico. Resultados: Quinze pacientes $(60 \%)$ relataram maior desconforto na introdução da cápsula $(p=0,327)$. Desconforto e limitações das atividades diárias foram menores no $2^{\circ}$ dia $(p<0,05)$; entretanto, continuaram sendo expressivos (32\% a $\left.44 \%\right)$. Dor torácica ocorreu em 13 (52\%) pacientes. O ganho diagnóstico no refluxo patológico foi de $12 \%$ com o sistema sem cateter $(p=0,355)$. Conclusões: 1$)$ Não há diferença significativa entre o desconforto relatado na introdução da cápsula e do cateter; 2 ) durante a monitorização do refluxo, o sistema sem cateter proporciona significativo menor desconforto e limitações das atividades diárias; 3 ) não há diferença significativa entre os dois métodos na capacidade de diagnosticar o refluxo patológico; 4) pHmetria sem cateter tem custo maior.

DESCRITORES: Refluxo gastroesofágico. Monitoramento do pH esofágico. Tecnologia sem fio.

\begin{tabular}{l} 
Central message \\
\hline Wireless pH monitoring provides better tolerability \\
(less discomfort and daily activities limitations); \\
however, it has higher cost and doesn't significantly \\
increase the diagnosis of the pathological \\
gastroesophageal acid reflux compared to \\
conventional esophageal pH monitoring.
\end{tabular}

\section{Perspective}

This is the first Brazilian study that simultaneously compared esophageal $\mathrm{pH}$ monitoring with and without catheter, demonstrating better tolerability in the capsule method. The high cost and inability to identify non-acid reflux limit the use of the wireless $\mathrm{pH}$ monitoring in clinical practice. The impedance$\mathrm{pH}$ monitoring, consolidated as a new gold standard for the diagnosis of gastroesophageal reflux, detects several types of reflux (acid, non-acid, liquid, gas).

From the ${ }^{1}$ Hospital das Clínicas, Departamento de Gastroenterologia, Faculdade de Medicina, Universidade de São Paulo, São Paulo, SP, Brasil; ${ }^{2}$ Faculdade de Medicina, Universidade de Santo Amaro, São Paulo, SP, Brasil ('Hospital das Clínicas, Department of Gastroenterology, Faculty of Medicine, University of São Paulo, São Paulo, SP, Brazil; ${ }^{2}$ Faculty of Medicine, University of Santo Amaro, São Paulo, SP, Brazil)

How to cite this article: Azzam RS, Azzam GB, Nasi A. Wireless pH monitoring and conventional esophageal pH monitoring: comparative study of discomfort, limitations in daily activities and complications. ABCD Arq Bras Cir Dig. 2021;34(1):e1566. DOI:/10.1590/0102-672020210001e1566

\section{Correspondence:}

Rimon Sobhi Azzam

E-mail: rimon.azzam@gmail.com

rimon.azzam@hc.fm.usp.br
Financial source: none

Conflict of interest: none

Received for publication: $10 / 06 / 2020$

Accepted for publication: 18/09/2020 
INTRODUCTION

E sophageal $\mathrm{pH}$ monitoring was introduced into clinical practice in in patients in the $70^{\prime} \mathrm{s}^{15}$. Flexible catheters and portable $\mathrm{pH}$ recorders began to be used in outpatients in the early 80 's. The prolonged ( 18 to $24 \mathrm{~h}$ ) pH monitoring of the distal esophagus allowed a quantitative measure of gastroesophageal reflux and a better understanding of the gastroesophageal reflux disease (GERD) $)^{5,6,15}$

An international Consensus Group developed a global definition of GERD as "the condition which develops when the reflux of stomach contents causes troublesome symptoms and/ or complications"29. The classic symptoms of GERD are heartburn (burning feeling in the retrosternal area) and regurgitation (perception of refluxed gastric contents into the mouth or pharynx) ${ }^{26}$

Upper gastrointestinal endoscopy and esophageal $\mathrm{pH}$ monitoring are the two methods directly related to GERD diagnosis ${ }^{21}$. The first method identifies the disease forms causing esophagitis, while the second diagnoses pathological gastroesophageal reflux ${ }^{21}$. Endoscopy also allows the collection of biopsy material for histological study, and such procedure is of fundamental importance in the study of the GERD complications ${ }^{21}$.

Esophageal $\mathrm{pH}$ monitoring is considered the gold standard for the diagnosis of pathological gastroesophageal acid reflux. The conventional method (with catheter) has sensitivity ranging from $79 \%$ to $96 \%$, specificity $85 \%$ to $100 \%$, and $98 \%$ accuracy $8,10,14,16,19,27,30$ The wireless method (without catheter and with capsule) has similar sensitivity and specificity $(78.3 \%$ to $100 \%$ and $84.5 \%$ to $94.8 \%$, respectively) ${ }^{23}$.

In clinical approach, the esophageal $\mathrm{pH}$ monitoring has precise indications and provides interesting details of the gastroesophageal acid reflux: assesses presence and intensity of acid reflux, characterizes reflux pattern (orthostatic, supine or combined), and associates clinical complaint with acid reflux episodes ${ }^{21}$.

However, during the monitored period, the conventional catheter is associated with nasal and throat discomfort and patients tend to exhibit reduced food intake and behave differently ${ }^{8,20}$. Although the wireless system has been developed to avoid restrictions and improve the diagnostic sensitivity, it's capsule may cause chest pain in up to $65 \%$ of cases $^{1,4,23,24,28,34}$.

This study was motivated by no local and few international publications concerning the comparative study of the discomfort and limitations in daily activities between wireless $\mathrm{pH}$ monitoring and conventional esophageal $\mathrm{pH}$ monitoring ${ }^{3}$.

The present study aimed to compare both esophageal $\mathrm{pH}$ monitoring, with and without catheter, concerning the degree of discomfort and restrictions in routine activities, complications, ability to diagnose pathological gastroesophageal reflux, and costs.

METHODS

This study was approved by the Ethics Committee for Analysis of Research Projects of the Clinical Hospital of the São Paulo University Medical School (number 1079/06).

Patients referred to the Esophageal Functional Investigation Laboratory of the Digestive System Surgery Department of the Clinical Hospital of the São Paulo University Medical School, São Paulo, Brazil, were prospectively screened for esophageal $\mathrm{pH}$ monitoring.

Inclusion criteria were: heartburn and/or regurgitation as the main clinical complaint; at least 18 years of age; recent upper gastrointestinal endoscopy (within the last two months); interruption in the administration of proton pump inhibitors for seven days preceding the $\mathrm{pH}$ monitoring; and signature of the free and informed consent form. Exclusion criteria were: esophageal diverticula, strictures and varices; hiatal hernia greater than or equal to $3 \mathrm{~cm}$; erosive esophagitis with Los Angeles Cor D grades;
Barrett's esophagus; and neoplasms, obstructive diseases or previous surgery of the gastrointestinal tract.

All patients underwent clinical interview, upper gastrointestinal endoscopy, nasal and oral esophageal manometry, $\mathrm{pH}$ monitoring with and without catheter (for 24 and $48 \mathrm{~h}$, respectively, with simultaneous initial period) and a specific clinical questionnaire of discomfort and limitations in daily activities.

The following GERD complaints were investigated during clinical interview: typical (heartburn and regurgitation), esophageal atypical (chest pain and globus sensation), and extraesophageal atypical (cough, asthma, dysphonia and hem).

All patients underwent endoscopy at the Gastrointestinal Endoscopy Department of the Clinical Hospital of the São Paulo University Medical School. The presence of erosive esophagitis and hiatal hernia were assessed. The Los Angeles grade system was used for the characterization of esophagitis; and the protrusion of part of the stomach $2 \mathrm{~cm}$ or more above the diaphragm, during deep inspiration, was considered hiatal hernia.

Beforeesophageal $\mathrm{pH}$ monitoring, a conventional esophageal manometry was performed to locate the loweresophageal sphincter (LES) for positioning the $\mathrm{pH}$ sensors.

\section{Esophageal $\mathrm{pH}$ monitoring}

After evaluating the distance of the LES, in relation to the nostril and to the upper dental arch through esophageal manometry, a catheter of the conventional esophageal $\mathrm{pH}$ monitoring was introduced, followed by the capsule of the wireless esophageal $\mathrm{pH}$ monitoring. Each patient underwent, with simultaneous monitoring recording starting time, conventional $\mathrm{pH}$ monitoring for 24 hours, and wireless $\mathrm{pH}$ monitoring for $48 \mathrm{~h}$.

The equipment used for the conventional $\mathrm{pH}$ monitoring consisted of portable $\mathrm{pH}$ recording device (Medtronic/Synectics, USA), $\mathrm{pH}$ calibration solutions and $\mathrm{pH}$ monitoring flexible catheter (Alacer, Brazil). The $2.1 \mathrm{~mm}$ in diameter catheter displayed two antimony sensors ( $2 \mathrm{~cm}$ away from each other) for $\mathrm{pH}$ registration and an external reference electrode. The catheter sensors were systematically calibrated before each test, using the calibration solutions at $\mathrm{pH} 7.0$ and $\mathrm{pH}$ 1.0. The distal sensor was positioned $3 \mathrm{~cm}$ above the superior border of the LES, which was identified through nasal esophageal manometry, to monitorate the reflux at a more distal level. The proximal sensor was positioned $5 \mathrm{~cm}$ above the superior border of the LES to monitorate the reflux at the internationally accepted standard position.

The wireless $\mathrm{pH}$ monitoring equipment (Bravo, Medtronic/ Synectics, USA) consisted of portable $\mathrm{pH}$ recording device, $\mathrm{pH}$ calibration solutions, $\mathrm{pH}$ monitoring capsule and capsule delivery device. The $\mathrm{pH}$ monitoring capsule, measuring $6.0 \times 6.3 \times 26.0 \mathrm{~mm}$, contained one antimony sensor, sensitive to $\mathrm{pH}$ changes, and an internal reference electrode. The capsule sensor was systematically calibrated before each test, using the same calibration solutions at $\mathrm{pH} 7.0$ and $\mathrm{pH}$ 1.0. The capsule was inserted through the mouth, with the assistance of the capsule delivery device that does not require endoscopy, and positioned in the esophagus, $3 \mathrm{~cm}$ above the superior border of the LES at the same level as the distal sensor of the conventional catheter. The suction system was applied by a vacuum pump $(510 \mathrm{mmHg}$ during $60 \mathrm{~s})$ and the esophagus mucosa penetrated into the capsule compartment (4 $\mathrm{mm}$ in diameter). The pin was released, transfixing the suctioned mucosa, while attaching the capsule to the esophageal wall. The vacuum was turned off and the capsule released from the distal end of the delivery device, which was removed. The $\mathrm{pH}$ recording was started and transmitted by radio waves (telemetry) to the portable recording device.

Patients were advised to try to maintain their daily activities, to fill out the $\mathrm{pH}$ monitoring log, and to return to the laboratory: after $24 \mathrm{~h}\left(1^{\text {st }}\right.$ day) to remove conventional $\mathrm{pH}$ monitoring system (catheter and external recording device); and again after another $24 \mathrm{~h}\left(2^{\text {nd }}\right.$ day) to remove the external recording device of the wireless $\mathrm{pH}$ monitoring system. 
It is noteworthy that parameters of normality for the characterization of pathological reflux were established by measuring reflux $5 \mathrm{~cm}$ above the LES and were only used in this study as reference values. The normal parameters used were: rate of total reflux time up to $4.5 \%$, rate of reflux time in an upright position up to $8.4 \%$, and rate of reflux time in a supine position up to $3.5 \%{ }^{14}$.

The patient was considered to be affected by pathological gastroesophageal reflux if any of the three percentages of reflux time adopted were at levels higher than normal; orhad quantitatively normal reflux, but with a significant relationship with the symptoms. The relationship between clinical complaint and gastroesophageal acid reflux was assessed by the Symptom Index and considered positive when equal or greater than $50 \%^{33}$.

Questionnaire of discomfort and limitations in daily activities

The patients also underwent a specific clinical questionnaire after removing each type of $\mathrm{pH}$ monitoring ( $1^{\text {st }}$ and $2^{\text {nd }}$ day), to compare the degree of discomfort and limitations in daily activities of the two types of esophageal $\mathrm{pH}$ monitoring. The questionnaire about the degree of discomfort and limitations in the daily activities was idealized by the authors, as long as there is no validated international questionnaire for this purpose. Parameters were considered. Initially, it was requested the patient to answer about the catheter and the capsule which bothered more to be introduced?

To evaluate the degree of discomfort and limitations in the daily activities during the first day of monitoring (in which the patient was simultaneously with the conventional catheter and the wireless capsule), in comparison with the second day (patient with the capsule, but without the catheter), it has been searched the interference in the routine activities, nasal discomfort, runny nose, cervical discomfort, feeding alteration, sleep disturbance, concern with the equipment, discomfort without bath and social constraint for the appearance of the equipment. For each item, the patient was requested to choose a number on a scale from zero to ten in accordance with the degree of discomfort. Zero was equivalent to the absence of discomfort and ten was an intense one. The discomfort degree was grouped in three categories: mild (score from 1 to 3 ), moderate (4 to 6 ) and intense (7 to 10 ).

Finally, for the following items of the questionnaire, it was requested the patient to answer yes or not: Did you leave house? Did you work? Did you have chest or epigastric pain? Would you repeat wireless $\mathrm{pH}$ monitoring if needed? and Would you repeat the conventional $\mathrm{pH}$ monitoring if needed?

\section{Statistical analysis}

For the statistical study, conducted at the Laboratory of Statistics and Epidemiology, Department of Gastroenterology, Clinical Hospital, São Paulo University Medical School, the following tests were used: bilateral proportion test, Friedman test, and unilateral proportiontest. Descriptivelevel of $p<0.05$ was considered significant.

RESULTS

Twenty-five patients meeting the inclusion criteria were enrolled in the study and submitted to the two types of esophageal $\mathrm{pH}$ monitoring (with and without catheter). Twenty-one (84\%) of which were females and the age ranged from 34 to 73 years (average 52.4). The clinical complaints were predominantly typical of GERD in all patients, esophageal atypical in 16 (64\%) and extraesophageal atypical in 19 (76\%). Upper gastrointestinal endoscopy revealed erosive esophagitis in 8 (32\%) patients and hiatal hernia in 11 (44\%).

Patients pointed a higher degree of discomfort in the introduction of both types of $\mathrm{pH}$ monitoring. Fifteen (60\%) pointed discomfort in the introduction of the capsule while 10 (40\%) with the catheter. Although most cases of discomfort occurred with the introduction of the capsule, such difference did not reached levels of statistical significance $(p=0,327)$.

In terms of the questions formulated in the specific clinical questionnaire, there was significant reduction in the degree of discomfort and limitations in the daily activities on the $2^{\text {nd }}$ day compared to the $1^{\text {st }}$ day on all the analyzed items $(p<0,05$, Table 1). However, in $2^{\text {nd }}$ day, an expressive contingent of patients still presented interference in the routine activities (36\%), cervical discomfort (32\%), feeding alteration (44\%), sleep disturbance (32\%) and concern with the equipment (44\%, Table 1).

Eleven (44.0\%) have left home in the $1^{\text {st }}$ day and 17 (68.0\%) in the $2^{\text {nd }}$ day of monitorization. Nine $(36.0 \%)$ have worked in $1^{\text {st }}$ day and 22 (88.0\%) in the $2^{\text {nd }}$ day of monitorization. It was observed that a large number of patients left home and worked in the $2^{\text {nd }}$ day of monitoring in relation to the $1^{\text {st }}$ day (leave home: $p=0,044$; work: $p<0.001)$. However, in the $2^{\text {nd }}$ day, an expressive contingent of patients (32\%) did not leave home.

Thirteen (52\%) patients presented chest or epigastric pain during the total period of monitorization.

When patients were inquired if there was a need for repetition of the examinations, 24 (96.0\%) affirmed that they would repeat the conventional $\mathrm{pH}$ monitoring and $22(88.0 \%)$ would repeat the wireless $\mathrm{pH}$ monitoring. It did not have a significant difference

TABLE 1 - Description and comparison of the discomfort degree on the 1st and 2nd day

\begin{tabular}{|c|c|c|c|c|c|c|c|}
\hline Degree of discomfort & Day & $\begin{array}{c}\text { Absence } \\
\text { n (\%) }\end{array}$ & $\begin{array}{l}\text { Mild } \\
\mathrm{n}(\%)\end{array}$ & $\begin{array}{c}\text { Moderate } \\
\text { n (\%) }\end{array}$ & $\begin{array}{c}\text { Intense } \\
\mathrm{n}(\%)\end{array}$ & $\begin{array}{c}\text { TOTAL } \\
\mathrm{n}\end{array}$ & $p^{1}$ \\
\hline Interference in routine activities & $\begin{array}{l}1^{\text {st }} \text { day } \\
2^{\text {nd }} \text { day }\end{array}$ & $\begin{array}{l}3(\mathbf{1 2}, 0) \\
16(64,0)\end{array}$ & $\begin{array}{c}9(36,0) \\
7(28,0)\end{array}$ & $\begin{array}{c}8(32,0) \\
2(8,0)\end{array}$ & $\begin{array}{c}5(20,0) \\
0(0,0)\end{array}$ & $\begin{array}{l}25 \\
25\end{array}$ & $0,001^{*}$ \\
\hline Nasal discomfort & $\begin{array}{l}1^{\text {st }} \text { day } \\
2^{\text {nd }} \text { day }\end{array}$ & $\begin{array}{l}5(20,0) \\
22(88,0)\end{array}$ & $\begin{array}{c}9(36,0) \\
1(4,0)\end{array}$ & $\begin{array}{c}3(\mathbf{1 2}, \mathbf{0}) \\
1(4,0)\end{array}$ & $\begin{array}{c}8(32,0) \\
1(4,0)\end{array}$ & $\begin{array}{l}25 \\
25\end{array}$ & $0,002^{*}$ \\
\hline Runny nose & $\begin{array}{l}1^{\text {st }} \text { day } \\
2^{\text {nd }} \text { day }\end{array}$ & $\begin{array}{l}5(\mathbf{2 0}, \mathbf{0}) \\
19(76,0)\end{array}$ & $\begin{array}{c}10(\mathbf{4 0 , 0 )} \\
4(16,0)\end{array}$ & $\begin{array}{c}6(24,0) \\
1(4,0)\end{array}$ & $\begin{array}{c}4(\mathbf{1 6}, \mathbf{0}) \\
1(4,0)\end{array}$ & $\begin{array}{l}\mathbf{2 5} \\
25\end{array}$ & $0,011^{*}$ \\
\hline Cervical discomfort & $\begin{array}{l}1^{\text {st }} \text { day } \\
2^{\text {nd }} \text { day }\end{array}$ & $\begin{array}{c}\mathbf{0}(\mathbf{0}, \mathbf{0}) \\
17(68,0)\end{array}$ & $\begin{array}{c}12(48,0) \\
2(8,0)\end{array}$ & $\begin{array}{c}5(20,0) \\
6(24,0)\end{array}$ & $\begin{array}{c}8(32,0) \\
0(0,0)\end{array}$ & $\begin{array}{l}25 \\
25\end{array}$ & $0,001^{*}$ \\
\hline Feeding alteration & $\begin{array}{l}1^{\text {st }} \text { day } \\
2^{\text {nd }} \text { day }\end{array}$ & $\begin{array}{l}9(36,0) \\
14(56,0)\end{array}$ & $\begin{array}{c}5(20,0) \\
5(20,0)\end{array}$ & $\begin{array}{l}6(24,0) \\
5(20,0)\end{array}$ & $\begin{array}{c}5(20,0) \\
1(4,0)\end{array}$ & $\begin{array}{l}25 \\
25\end{array}$ & $0,011^{*}$ \\
\hline Sleep disturbance & $\begin{array}{l}1^{\text {st }} \text { day } \\
2^{\text {nd }} \text { day }\end{array}$ & $\begin{array}{c}11(44,0) \\
17(68,0)\end{array}$ & $\begin{array}{c}4(16,0) \\
6(24,0)\end{array}$ & $\begin{array}{l}2(8,0) \\
2(8,0)\end{array}$ & $\begin{array}{c}8(32,0) \\
0(0,0)\end{array}$ & $\begin{array}{l}25 \\
25\end{array}$ & $0,003^{*}$ \\
\hline Concern with the equipment & $\begin{array}{l}1^{\text {st }} \text { day } \\
2^{\text {nd }} \text { day }\end{array}$ & $\begin{array}{l}6(24,0) \\
14(56,0)\end{array}$ & $\begin{array}{l}6(24,0) \\
5(20,0)\end{array}$ & $\begin{array}{l}5(20,0) \\
4(16,0)\end{array}$ & $\begin{array}{c}8(32,0) \\
2(8,0)\end{array}$ & $\begin{array}{l}25 \\
25\end{array}$ & $0,003^{*}$ \\
\hline Discomfort without bath & $\begin{array}{l}1^{\text {st }} \text { day } \\
2^{\text {nd }} \text { day }\end{array}$ & $\begin{array}{c}\mathbf{2}(\mathbf{8}, \mathbf{0}) \\
25(100,0)\end{array}$ & $\begin{array}{c}5(20,0) \\
0(0,0)\end{array}$ & $\begin{array}{c}3(12,0) \\
0(0,0)\end{array}$ & $\begin{array}{c}15(60,0) \\
0(0,0)\end{array}$ & $\begin{array}{l}25 \\
25\end{array}$ & $0,000^{*}$ \\
\hline Social constraint & $\begin{array}{l}1^{\text {st }} \text { day } \\
2^{\text {nd }} \text { day }\end{array}$ & $\begin{array}{l}13(52,0) \\
23(92,0)\end{array}$ & $\begin{array}{c}5(20,0) \\
1(4,0)\end{array}$ & $\begin{array}{l}1(4,0) \\
1(4,0)\end{array}$ & $\begin{array}{c}6(24,0) \\
0(0,0)\end{array}$ & $\begin{array}{l}25 \\
25\end{array}$ & $0,008^{*}$ \\
\hline
\end{tabular}


between the two types of $\mathrm{pH}$ monitoring due to the patient's decision to repeat the examination, in case of necessity $(p=0,297)$.

Pathological gastroesophageal reflux was detected by the conventional method in 16 (64\%) patients and by the wireless method in 19 (76\%). However, this $12 \%$ increase in the diagnostic gain has no statistical difference $(p=0.355)$.

With regard to complications, the early capsule drop has occurred in one (4\%) patient during the wireless method exam and there was no relevant technical failure in the group monitored with catheter. There was no significant difference between the two types of $\mathrm{pH}$ monitoring concerning technical failure during examination $(p=0.463)$. No patient experienced severe chest pain or any other symptom requiring endoscopic removal of the capsule. On the $30^{\text {th }}$ day after the capsule insertion, the spontaneous detachment of the capsule from the esophageal wall was confirmed in all patients, in the study by a lateral chest $\mathrm{X}$-ray. Esophageal perforation, migration, aspiration or other complications have not occurred in any case.

About the expenses, the capsule (single use) costs $\$ 411.53$ and the catheter (reused for five times) \$39.22; so, the catheter costs only $\$ 7.84$ per use.

\section{DISCUSSION}

This is the first Brazilian study that compares the esophageal $\mathrm{pH}$ monitoring with and without catheter regarding discomfort, limitations in daily activities, complications and costs. However, the small number of patients is a limitation of this study; this restriction occurred due to the cost of the capsules.

It was observed that $68.0 \%$ of the cases submitted to endoscopy did not have erosive esophagitis; in this group of patients, esophageal $\mathrm{pH}$ monitoring was indicated for diagnosis or exclusion of non-erosive GERD. In 32.0\% with erosive esophagitis, $\mathrm{pH}$ monitoring was indicated to characterize the reflux pattern.

Classical contraindications described in the literature of the wireless $\mathrm{pH}$ monitoring system are important limitations to the method and include: severe esophagitis, esophageal varices, bleeding diathesis, anticoagulation, stricture or obstruction of the gastrointestinal tract, and the use of cardiac pacemaker or defibrillator ${ }^{25}$. It should be noted that such conditions do not represent contraindications to the conventional $\mathrm{pH}$ monitoring with catheter. The impossibility of properly fixing the capsule in an area of esophagitis, with intense degree of inflammatory process, prevents the evaluation of $\mathrm{pH}$ monitoring reflux in an important group of patients with GERD. The capsule is released spontaneously after a few days and is eliminated by the digestive tract; however, the presence of stenosis or obstruction of the gastrointestinal tract would cause capsule impaction.

Exclusion criteria for this study included esophageal diverticula due to the risk of perforation during the capsule introduction. It should be emphasized that the wireless $\mathrm{pH}$ monitoring may have limited use in patients under investigation of non-cardiac chest pain, because the capsule can cause chest pain, making it difficult to discern pain caused by the capsule rather than reflux or heart. The capsule contains a small magnet; therefore, a Magnetic Resonance is not recommended within 30 days after insertion of the capsule due to the risk of perforation if the capsule has not been completely eliminated. These restrictions also do not apply to conventional $\mathrm{pH}$ monitoring with catheter.

Possible contraindications to wireless system should be carefully evaluated before the test and if they are noted, a conventional $\mathrm{pH}$ monitoring with catheter should be performed ${ }^{25}$. Patients should also be informed about the risks of wireless $\mathrm{pH}$ monitoring: discomfort, chest pain, dysphagia, odynophagia, foreign body sensation, nausea, vomiting, laryngospasm, vasovagal reaction, capsule fixation failure, premature capsule detachment, failure of the capsule detachment, capsule migration, capsule aspiration, capsule retention, esophageal tear or ulcer, bleeding, perforation and possible endoscopic or surgical procedure to solve complications.
The comparative study between wireless and conventional esophageal $\mathrm{pH}$ monitoring was conducted at a lower traditional level of the esophagus. Reasons for this choice included: changes in the mucosa due to GERD commonly occur next to the esophagogastric junction; feasibility study of inserting the capsule closest to this transition zone; and, at a lower level, compare discomfort, activity restrictions, complications and pathological gastroesophageal reflux detection between the two types of $\mathrm{pH}$ monitoring sensors (capsule vs. catheter).

The present and Andrews et al. ${ }^{2}$ studies observed that there was no significant difference between the capsule or catheter introduction. However, Gillies et al. ${ }^{11}$ showed less discomfort in the introduction of the capsule $(p<0.0001)$.

Studying catheter interference in daily activities of patients only submitted to conventional esophageal pH monitoring, Fass et al. ${ }^{8}$ demonstrated a significant reduction in duration of activities (patient tends to be more sedentary on exam day), number of meals, and frequency of reflux symptoms during monitoring.

By comparing discomfort and interference in routine activities between wireless and conventional $\mathrm{pH}$ test, during the monitoring, Andrews et al., Gillies et al., and Wong et al.2,11,34 observed better tolerability of the capsule. There was significantly less discomfort (nasal pain, runny nose, cervical pain, cervical discomfort and headache), as well as less interference in daily activities (general activities, eating, work and sleep) 2,11,34. However, Andrews et al. ${ }^{2}$ showed more thoracic discomfort in the wireless $\mathrm{pH}$ monitoring than in the conventional $\mathrm{pH}$ monitoring $(\mathrm{p}=0.001)$.

Maerten et al. ${ }^{18}$ describe that the main inconvenience of wireless $\mathrm{pH}$ monitoring is the induction of thoracic discomfort, which may range from mild foreign body sensation to intense thoracic pain, resulting from the capsule fixation on the esophageal wall. In the present study, thoracic or epigastric pain was observed during monitoring in $52 \%$ of patients. This finding is consistent with the literature, which shows chest pain from $10.5 \%$ to $65 \%$ of patients undergoing wireless $\mathrm{pH}$ monitoring ${ }^{1,4,23,24,28,34}$. Studying the presence of symptoms related to the capsule, Remes-Troche et al. ${ }^{11}$ observed: chest pain (in 33\% of cases), foreign body sensation (14\%), nausea (6\%) and more than one symptom in $11 \%$ of the cases.

The finding of $4 \%$ of early drop of the capsule during wireless $\mathrm{pH}$ monitoring supports literature data, indicating that this technical failure occurred in $4.1 \%$ to $5 \%$ of cases $^{4,11,24}$.

With chest radiological control on the $14^{\text {th }}$ day, Lin et al. ${ }^{17}$ observed that the capsule remained in $1 \%$ of cases. There are reports of endoscopic capsule removal in $1.4 \%$ to $3.5 \%$ of cases $^{1,4}$ and the most common reason for withdrawal was severe chest pain ${ }^{23}$.

Other rare complications of the wireless $\mathrm{pH}$ monitoring reported in the literature are: esophageal perforation during insertion, esophageal ulcer, capsule dislodgement in the pyriform sinus, capsule migration to the nasopharynxafter cough, aspiration of the capsule into the lower lobe bronchus, and capsule retention in a colon diverticulum ${ }^{7,9,12,13,31,32}$. Because of this complication, we believe that a simple abdominal $\mathrm{x}$-ray should also be required for complete evaluation of the capsule elimination.

The present study effectively proved that, during monitoring, the wireless $\mathrm{pH}$ monitoring provides a significant reduction in the degree of discomfort and limitations in daily activities; however, it was evidenced that the presence of the capsule was associated with chest pain in an expressive number of patients. Moreover, it proved that better tolerability does not provide a significant increase in the diagnostic sensitivity of GERD; this fact is corroborated by the literature review published by Maerten et $\mathrm{al}^{18}$.

Wireless $\mathrm{pH}$ monitoring is a high cost procedure, limiting its use in daily practice, and it has no ability to identify non-acid reflux. Impedance-pH monitoring is a promising method that detects several types of reflux (acid, non-acid, liquid, gaseous), evaluates otherimportantmeasures (esophagus ability to transport the bolus, basal mucosal impedance and post-reflux primary peristalsis) and is consolidated as a new gold standard for the diagnosis of gastroesophageal reflux $x^{21,22}$. 
CONCLUSIONS

It can be concluded that: 1) there is no significant difference between the discomfort in the introduction of the wireless $\mathrm{pH}$ monitoring capsule and the $\mathrm{pH}$ monitoring catheter; 2) during reflux monitoring, wireless $\mathrm{pH}$ test provides significant less discomfort and limitations in daily activities compared to conventional $\mathrm{pH}$ monitoring; 3 ) despite the better tolerability of the capsule, there is no significant difference between the two $\mathrm{pH}$ monitoring methods in the ability to diagnose pathological gastroesophageal reflux; 4) wireless $\mathrm{pH}$ monitoring has higher cost.

\section{REFERENCES}

1. Ahlawat SK, Novak DJ, Williams DC, Maher KA, Barton F, Benjamin $\mathrm{SB}$. Day-to-day variability in acid reflux patterns using the Bravo $\mathrm{pH}$ monitoring system. J Clin Gastroenterol. 2006;40:20-4.

2. Andrews CN, Sadowski DC, Lazarescu A, Williams C, Neshev E, Storr M et al. Unsedated peroral wireless $\mathrm{pH}$ capsule placement vs. standard $\mathrm{pH}$ testing: a randomized study and cost analysis. BMC Gastroenterol. 2012;12:58.

3. Azzam RS. Comparative study of two modes of gastroesophageal reflux measuring: conventional esophageal $\mathrm{pH}$ monitoring and wireless $\mathrm{pH}$ monitoring [dissertation]. São Paulo (SP): São Paulo University; 2009.

4. BhatYM,McGrathKM,BielefeldtK.WirelessesophagealpHmonitoring:new techniquemeansnewquestions. JClin Gastroenterol.2006:40(2):116-21.

5. Braghetto I, Csendes A. Failure after fundoplication: re-fundoplication? Is there a room for gastrectomy? In which clinical scenaries? ABCD Arq Bras Cir Dig. 2019:32(2):e1440. ISSN 0102-672.

6. Dib VRM, Ramos AC, Kawahara NT, Campos JM, Marchesini JC, GalvãoNeto $M$, et al. Does weight gain, throughout 15 years follow-up after Nissen laparoscopic fundoplication, compromise reflux symptoms control? ABCD Arq Bras Cir Dig. 2020;33(1):e1488. ISSN 0102-6720.

7. Fajardo NR, Wise JL, Locke GR 3rd, Murray JA, Talley NJ. Esophagea perforation after placement of wireless Bravo $\mathrm{pH}$ probe. Gastrointest Endosc. 2006;63:184-5.

8. Fass R, Hell R, Sampliner RE, Pulliam G, Graver E, Hartz V, et al. Effect of ambulatory 24-hour esophageal $\mathrm{pH}$ monitoring on reflux-provoking activities. Dig Dis Sci. 1999;44:2263-9.

9. Francis DL. Attachment disorder: a decline in the performance of the Bravo pH system. Am J Gastroenterol. 2008;103(10):2663.

10. FuchsKH,DeMeesterTR,AlbertucciM.Specificityand sensitivityofobjective diagnosis of gastroesophageal reflux disease. Surgery. 1987;102:575-80.

11. Gillies RS, Stratford JM, Booth MI, DehnTCB. Oesophageal pH monitoring using the Bravo catheter-free radio capsule. Eur J Gastroenterol Hepatol. 2007:19(1):57-63.

12. Haseeb A, Lateef N, Bilal M, Gaurav K, Prudom J, Musani A. Bravo capsule aspiration: a rare case report. Cureus. 2017;9(8):e1556

13. Hogan RB, Phillips $P$, Boyd SA, Williams JC. Two-year retention of Bravo capsuleinagiantcolonicdiverticulum.AmJ Gastroenterol.2009;104:1062-3.

14. Jamieson JR, Stein HJ, DeMeester TR, Bonavina L, Schwizer W, Hinde $\mathrm{RA}$, et al. Ambulatory 24-h esophageal $\mathrm{pH}$ monitoring: normal values, optimal thresholds, specificity, sensitivity, and reproducibility. Am J Gastroenterol. 1992:87:1102-11.

15. Johnson LF, DeMeester TR. Twenty-four hour $\mathrm{pH}$ monitoring of the distal esophagus: a quantitative measure of gastroesophageal reflux. Am J Gastroenterol. 1974:62:325-32.
16. Johnsson F, Joelsson B, Isberg PE. Ambulatory 24 hour intraesophageal $\mathrm{pH}$-monitoring in the diagnosis of gastroesophageal reflux disease. Gut. 1987:28:1145-50.

17. LinE, Waring JP, Ramaswamy A. Analysis of 245 consecutive studies using 48-hourwirelesspH(Bravo)probesforGERDevaluation.Gastroenterology. 2003;124:A689.

18. Maerten P,OrtnerM, MichettiP,DortaG. WirelesscapsulepHmonitoring does it fulfil all expectations? Digestion. 2007;76:235-40.

19. Mattioli S, Pilotti V, Spangaro M, Grigioni WF, Zannoli R, Felice V, et al. Reliability of 24-hour home esophageal $\mathrm{pH}$ monitoring in diagnosis of gastroesophageal reflux. Dig Dis Sci. 1989;34:71-8.

20. Mearin F, Balboa A, Dot J, Maldonado O, Malagelada JR. How standard is a standard day during a standard ambulatory 24-hour esophageal pH monitoring? Scan J Gastroenterol. 1998;33:583-5.

21. Nasi A, Moraes-Filho JPP, Cecconello I. Gastroesophageal reflux disease: an overview. Arq Gastroenterol. 2006:43(4):334-41.

22. Nasi A, Queiroz NSF, Michelsohn NH. Prolonged gastroesophageal reflux monitoring by impedance-pHmetry: a review of the subject pondered with our experience with 1,200 cases. Arq Gastroenterol. 2018;55 Suppl 1:76-84.

23. Pandolfino JE, Richter JE, Ours T, Guardino JM, Chapman J, Kahrilas PJ. Ambulatory esophageal $\mathrm{pH}$ monitoring using a wireless system. Am J Gastroenterol. 2003;98:740-9.

24. Remes-Troche JM, Ibarra-Palomino J, Carmona-Sánchez RI, Valdovinos MA. Performance, tolerability, and symptoms related to prolonged $\mathrm{pH}$ monitoring using the Bravo system in Mexico. Am J Gastroenterol. 2005;100(11):2382-6.

25. Richter JE, Pandolfino JE, Vela MF, Kahrilas PJ, Lacy BE, Ganz R, et al. Utilization of wireless $\mathrm{pH}$ monitoring technologies: a summary of the proceedings from the esophageal diagnostic working group. Diseases of the Esophagus. 2013;26(8):755-65.

26. RichterJE,RubensteinJH.Presentationandepidemiologyofgastroesophageal reflux disease. Gastroenterology. 2018;154(2):267-76.

27. Schindlbeck NE, Heinrich C, König A, Dendorfer A, Pace F, Müller-Lissner SA.Optimal thresholds, sensitivity, and specificity oflong-term $\mathrm{pH}$-metry for the detection of gastroesophageal reflux disease. Gastroenterology. 1987;93:85-90.

28. Tharavej C, Hagen JA, Portale G, Hsieh CC, Gandamihardja TA, Lipham $J$, et al. Bravo capsule induction of esophageal hypercontractility and chest pain. Surg Endosc. 2006;20(5):783-6.

29. Vakil N, van Zanten SV, Kahrilas P, Dent J, Jones R, Global Consensus Group. The Montreal definition and classification of gastroesophageal reflux disease: a global evidence-based consensus. Am J Gastroenterol. 2006;101(8):1900-20.

30. Vitale GC, Sadek S, Tulley FM, Rimmer AR, Hunter BE, Phelan J, et al. Computerized 24-hour esophageal pH monitoring: a new ambulatory technique using radiotelemetry. J Lab Clin Med. 1985;105:686-93.

31. von Renteln D, Kayser T, Riecken B, Caca K. An unusual case of Bravo capsule aspiration. Endoscopy. 2008;40 Suppl 2:E174.

32. Wells CD, Heigh RI, Burdick GE, Moirano MM, Fleischer DE. Symptomatic esophageal ulceration caused by a Bravo wireless $\mathrm{pH}$ probe and subsequent endoscopic removal of the probe using a retrieval net. Endoscopy. 2006;38(Suppl 2):E97.

33. Wiener GJ, RichterJE, CooperJB, WuWC, CastellDO. The symptomindex a clinically important parameter of ambulatory 24-hour esophageal $\mathrm{pH}$ monitoring. Am J Gastroenterol. 1988;83:358-61.

34. Wong WM, Bautista J, Dekel R, Malagon IB, Tuchinsky I, Green C, et al. Feasibility and tolerability of transnasal/per oral placement of the wireless $\mathrm{pH}$ capsule vs traditional 24-h oesophageal $\mathrm{pH}$ monitoring: a randomized trial. Aliment Pharmacol Ther. 2005;21:155-63. 